\title{
Effects of Corn Distillers Dried Grain with Solubles on Growth Performance and Economic Benefit of Meat Ducks
}

\author{
Xiaopeng Tang ${ }^{1, *}$, Lei Chen ${ }^{1}$, Kangning Xiong ${ }^{1}$, Dun Deng ${ }^{2}$ and Peng Peng ${ }^{2, *}$ \\ ${ }^{1}$ State Key Laboratory Cultivation for Karst Mountain Ecology Environment of Guizhou \\ Province, School of Karst Science, Guizhou Normal University, Guiyang, China \\ ${ }^{2}$ Tangrenshen Group, Zhuzhou, China
}

\begin{abstract}
A B S T R A C T
This study aims to investigate the effects of different levels of corn distillers dried grain with solubles (DDGS) on the growth performance of meat ducks. To this end, a total of 450 Shuanggui-tou meat ducks with comparable body weights were treated with increasing concentration of DDGS. Compared to mock-treated group, the average daily gain (ADG), average daily feed intake (ADFI) and feed to meat ratio $(F: G)$ were measured. It was revealed that the addition of DDGS up to $24 \%$ in the diet remained ineffective for ADFI, ADG and F:G. However, there a tendency of decrease in ADG was observed when $32 \%$ DDGS was added in the feed. Taken together, our results demonstrate that the increase of DDGS in feed did not negatively affect the growth performance and subsequently can decrease the cost per unit weight gain. Therefore, the DDGS presents an alternative protein resource to meet ever-increasing demands of feed ingredients in poultry production sectors
\end{abstract}

\begin{tabular}{l} 
Article Information \\
Received 21 May 2019 \\
Revised 27 July 2019 \\
Accepted 20 August 2019 \\
Available online 05 March 2021 \\
Authors' Contribution \\
\hline XT and PP designed and performed \\
the experiments. XT and LC wrote the \\
paper. KX and DD revised the paper. \\
Key words \\
Corn distillers dried grain with \\
solubles, Economic benefit, Growth \\
performance, Meat duck.
\end{tabular}

\section{INTRODUCTION}

$\mathrm{W}$ ith the continuous growth of livestock and poultry sectors, the shortage of feed ingredients (especially protein feed resources) is becoming a serious concern around the globe including China. To resolve this worldwide problem, development and utilization of unconventional and alternative protein resources have been considered (Xie et al., 2016). One of such alternatives is distillers dried grains with solubles (DDGS) which is a by-product of dry-grind ethanol production from various cereal grains including corn, sorghum, wheat and rye (Xu et al., 2010; Liu and Han, 2011; Villela et al., 2017). Corn DDGS is one of the most abundant by-products in ethanol processing and has commonly been used as a replacement for soybean meal in animal feeds due to its high concentration of energy, protein, amino acids, phosphorus, and its relatively low market price (Fastinger et al., 2006; Kowalczyk et al., 2012; Villela et al., 2017). Previous studies have demonstrated that corn DDGS can be satisfactorily used in broilers diets (Kim et al., 2018; Shim et al., 2018), and feed for laying hens (Wang et al., 2018), rabbits (Alagón et al., 2015), fishes (Diógenes, et al., 2018), pigs

\footnotetext{
* Corresponding authors: tangxiaopeng110@126.com; pp20130515@163.com 0030-9923/2021/0003-0821 \$ 9.00/0

Copyright 2021 Zoological Society of Pakistan
}

(Yang et al., 2017; Huang et al., 2018; Oczkowicz et al., 2018), cattle (He et al., 2014), cows (Testroet et al., 2018), laying ducks (Ruan et al., 2018) as well as meat ducks (Adamski et al., 2011; Kowalczyk et al., 2012).

However, the field application of corn DDGS in poultry is mainly limited to broilers and laying hens feed. The application of corn DDGS in meat duck feed has rarely been documented. Owing to differences in digestive tract characteristics between duck and chicken, the capacity and weight of the visceral organs of duck are larger than that of chicken. Therefore, we hypothesized that meat duck can tolerate higher levels of DDGS compared to chicken and we set to study the effect of different levels of corn DDGS on the growth performance and economic benefit in meat ducks. These understandings would guide the revised feed formulation and field application of alternative feed in meat ducks in enhancing productivity and performance.

\section{MATERIALS AND METHODS}

\section{Corn DDGS}

Corn DDGS used in this study was imported from the United States of America. The nutritional values of corn DDGS were measured before usage. The chemical composition of DDGS (air-dry basis) was as follows: crude protein (CP) $25.00 \%$, crude fat (EE) $10.00 \%$, lys $0.70 \%$, met $0.50 \%$, total phosphate $0.75 \%$, available phosphate $0.40 \%$, calcium $0.05 \%$, and metabolic energy (ME) 2650 
$\mathrm{kcal} / \mathrm{kg}$.

\section{Animals}

All animal studies were approved by the Animal Care Committee of Guizhou Normal University Guiyang, China. The experimental procedures were conducted in accordance with the Chinese Guidelines for Animal Welfare. Shuanggui-tou meat ducks, a cross between Peking duck and Hemp duck, were provided by Tangrenshen Group (Zhuzhou, China).

\section{Experiment design and diets}

A total of 450 Shuanggui-tou meat ducks (fifteenday-old) with similar weight $(443.89 \pm 13.2 \mathrm{~g})$ were divided into 5 treatments: T0 (control group, 0\% DDGS), T1 (8\% DDGS in the diet), T2 (16\% DDGS in the diet), T3 (24\% DDGS in the diet), and T4 (32\% DDGS in the diet). Each treatment carried 6 replicates, and each replicate was composed of 15 ducks. The composition and nutrition level of the diets is shown in Table I. All diets were formulated to meet nutrient requirements of meattype duck (NY/T 2122-2012). The ducks were housed in an environmentally controlled room with a $24 \mathrm{~h}$ constant light schedule and ad libitum access to water and feed. Ducks were weighted by pen, and feed consumption was recorded weekly. The average daily gain (ADG), average daily feed intake (ADFI) and feed to meat ratio (F:G) were measured. The regression relationship between DDGS and ADG, the regression relationship between DDGS and F:G were analyzed and the economic benefit of adding DDGS in duck diets was assessed. The experiment lasted for a total of 28 days.

\section{Statistical analysis}

All data were presented as mean \pm standard deviation (SD). Results of growth performance were analysed by One-Way ANOVA using the SPSS 21.0 programs (SPSS, Inc., Chicago, IL, USA). Differences among treatment mean were determined using Duncan's multiple comparison tests. The regression relationship between DDGS and ADG, DDGS and F:G were analysed by quadratic regression analysis of SPSS 21.0 programs (SPSS, Inc., Chicago, IL, USA). A $P<0.05$ was considered significant whereas $P<0.1$ was considered as significant tendency.

Table I.- Diet composition and nutrient levels (on fed basis, \%).

\begin{tabular}{|c|c|c|c|c|c|}
\hline Ingredients & $\mathrm{TO}^{1}$ & T1 & T2 & T3 & T4 \\
\hline Corn & 53.00 & 49.00 & 45.00 & 41.00 & 36.50 \\
\hline Corn DDGS & 0.00 & 8.00 & 16.00 & 24.00 & 32.00 \\
\hline Soybean meal & 4.00 & 0.00 & 0.00 & 0.00 & 0.00 \\
\hline Cottonseed meal & 4.00 & 4.00 & 0.00 & 0.00 & 0.00 \\
\hline Rapeseed meal & 8.00 & 8.00 & 8.00 & 3.50 & 0.00 \\
\hline Meat meal & 2.00 & 2.00 & 2.00 & 2.00 & 1.50 \\
\hline Wheat middling & 12.00 & 12.00 & 12.00 & 12.00 & 12.00 \\
\hline Oil bran & 13.00 & 13.00 & 13.00 & 13.00 & 13.00 \\
\hline $\mathrm{CaHPO}_{4}$ & 0.70 & 0.60 & 0.55 & 0.50 & 0.50 \\
\hline Salt & 0.35 & 0.35 & 0.35 & 0.35 & 0.35 \\
\hline Limestone & 0.20 & 0.20 & 0.20 & 0.25 & 0.35 \\
\hline Lysine & 0.50 & 0.60 & 0.65 & 0.70 & 0.70 \\
\hline Methionine & 0.07 & 0.06 & 0.05 & 0.04 & 0.04 \\
\hline Mildew preventive & 0.05 & 0.05 & 0.05 & 0.05 & 0.05 \\
\hline Zeolite powder & 1.13 & 1.14 & 1.15 & 1.61 & 2.01 \\
\hline Premix $^{2}$ & 1.00 & 1.00 & 1.00 & 1.00 & 1.00 \\
\hline Total & 100 & 100 & 100 & 100 & 100 \\
\hline \multicolumn{6}{|l|}{ Nutrient levels ${ }^{3}$} \\
\hline $\mathrm{ME}(\mathrm{kcal} / \mathrm{Kg})$ & 2773 & 2767 & 2776 & 2781 & 2778 \\
\hline $\mathrm{CP}$ & 15.40 & 15.41 & 15.45 & 15.49 & 15.50 \\
\hline Lys & 0.85 & 0.85 & 0.86 & 0.86 & 0.86 \\
\hline Met & 0.32 & 0.32 & 0.32 & 0.32 & 0.31 \\
\hline Met+Cys & 0.61 & 0.62 & 0.62 & 0.61 & 0.61 \\
\hline $\mathrm{Ca}$ & 0.83 & 0.82 & 0.82 & 0.83 & 0.82 \\
\hline Total Pi & 0.72 & 0.72 & 0.73 & 0.72 & 0.70 \\
\hline Available Pi & 0.35 & 0.35 & 0.35 & 0.35 & 0.35 \\
\hline
\end{tabular}

${ }^{1} \mathrm{~T} 0$, control group: 0\% DDGS; T1, 8\% DDGS; T2, 16\% DDGS; T3, 24\% DDGS; T4, 32\% DDGS. ${ }^{2}$ The premix provided following per kilogram of diet: $\mathrm{Cu} 20 \mathrm{mg}$, Fe $90 \mathrm{mg}$, Mn $70 \mathrm{mg}, \mathrm{Zn} 60 \mathrm{mg}$, I $0.38 \mathrm{mg}$, Se $0.20 \mathrm{mg}$, VA $3000 \mathrm{IU}$, VE $10 \mathrm{mg}, \mathrm{VD}_{3} 500 \mathrm{IU}, \mathrm{VK} 0.5 \mathrm{mg}, \mathrm{VB}_{1} 2 \mathrm{mg}, \mathrm{VB}_{2} 5 \mathrm{mg}$, $\mathrm{VB}_{6} 4 \mathrm{mg}$, nicotinic acid $20 \mathrm{mg}, \mathrm{VB}_{12} 12 \mu \mathrm{g}$, D-pantothenic acid $15 \mathrm{mg}$, folic acid $550 \mu \mathrm{g}$. ${ }^{3}$ nutrient levels were calculated values.

Table II.- Effects of corn DDGS on the performance of meat ducks (g, g/d).

\begin{tabular}{lcccccc}
\hline Item & T0 $^{1}$ & T1 & T2 & T3 & T4 & P-value \\
\hline ADFI $^{2}$ & $154.02 \pm 7.11$ & $153.71 \pm 5.26$ & $153.35 \pm 2.75$ & $150.30 \pm 3.19$ & $151.15 \pm 3.27$ & 0.546 \\
ADG & $51.53 \pm 2.07$ & $52.42 \pm 2.41$ & $51.65 \pm 2.23$ & $51.45 \pm 1.21$ & $50.86 \pm 3.03$ & 0.831 \\
F:G & $2.99 \pm 0.12$ & $2.93 \pm 0.09$ & $2.97 \pm 0.09$ & $2.92 \pm 0.10$ & $2.97 \pm 0.15$ & 0.798 \\
\hline
\end{tabular}

${ }^{1} \mathrm{~T} 0$, control group: $0 \%$ DDGS; T1, 8\% DDGS; T2, 16\% DDGS; T3, 24\% DDGS; T4, 32\% DDGS. ${ }^{2} \mathrm{ADFI}$, average daily feed intake; ADG, average daily gain; $\mathrm{F}$ :G, feed to meat ratio. 


\section{RESULTS AND DISCUSSION}

\section{Effects of corn DDGS on growth performance of meat ducks}

The growth performance analysis of DDGS in meat ducks showed a non-significant effect on the ADFI, ADG and F:G o $(P>0.05)$ (Table II). When DDGS was supplemented up to $24 \%$, there was no difference in ADG between the experimental group and the control group $(P>$ $0.05)$, but there was a tendency of decrease in ADG when DDGS was added to $32 \%(0.05<P<0.1)$. Corn DDGS is a high-quality protein feedstuff for poultry. Previous studies in broilers showed that the recommend DDGS levels are non-identical. Dozier et al. (2016) have indicated that, addition of $8 \%$ DDGS in the starter, $10 \%$ DDGS in the grower, $12 \%$ DDGS in finisher 1 and 14\% DDGS in finisher 2 periods did not affect cumulative growth and carcass characteristics of broilers from 1 to 50 days of age. On the other hands, Wang et al. (2007) have suggested that $20 \%$ corn DDGS could be used in broiler diets based on digestible amino acids. It have also been reported that $25 \%$ DDGS was acceptable in broiler diets. Addition of $10 \%$, $20 \%$ or $30 \%$ corn DDGS in starter, grower and finisher diets would not affect the performance of Chinese yellow broiler, a typical broiler chicken from 1 to 63 days of age (Shim et al. (2011) and Ruan et al. (2017).

The digestive tract of duck is anatomically different than that of chicken. Therefore, the capacity and weight of the visceral organs of duck is larger than that of chicken. The results obtained from this study indicated that growth performance of meat ducks was not influenced by dietary DDGS added to $32 \%$, further justifying the hypothesis. It is imperative to state that ducks are usually considered as a 'bioindicators' to feed quality, due to their sensitivity to any nutrient deficiency (Kowalczyk et al., 2012). Results presented here indicate that addition of DDGS in diet was harmless for growth performance of ducks. This indicates that DDGS can be proposed as a good alternative for soybean meal in duck feeds. These results are consistent with the report of previous study which showed that DDGS supplementation up to $30 \%$ in Pekin diets did not negatively affect live body weight (Adamski et al., 2011). However, corn DDGS contains high level of unsaturated fatty acids, particularly oleic acid and linoleic acid which are prone to oxidation. This may subsequently result in an acceleration of lipid oxidation in muscle and ultimately affecting the meat quality (Hanson et al., 2015; Min et al., 2015; Ruan et al., 2018). In order to optimize a suitable level of DDGS for meat duck diets, the regression relationship between DDGS and ADG, DDGS and F:G was calculated. As shown in Figure 1, the regression relationship between DDGS and ADG was $\mathrm{y}=-26.674 \mathrm{x}^{2}+5.6482 \mathrm{x}+51.70\left(\mathrm{R}^{2}=0.7543, P>0.05, \mathrm{y}\right.$ is ADG; $x$ represents DDGS addition level) (Fig. 1A) and the regression relationship between DDGS and $F: G$ was $\mathrm{y}=1.4509 \mathrm{x}^{2}-0.5268 \mathrm{x}+2.9846\left(\mathrm{R}^{2}=0.414, P>0.05\right.$, $\mathrm{y}$ is $\mathrm{F}: \mathrm{G}$, $\mathrm{x}$ represents DDGS addition level) (Fig. 1B). According to the quadratic regression equation, it can be speculated that the maximum ADG would be $52.00 \mathrm{~g} / \mathrm{d}$ when DDGS addition level was $10.58 \%$, and the lowest $F$ : G would be 2.93 when DDGS addition level was $18.15 \%$.
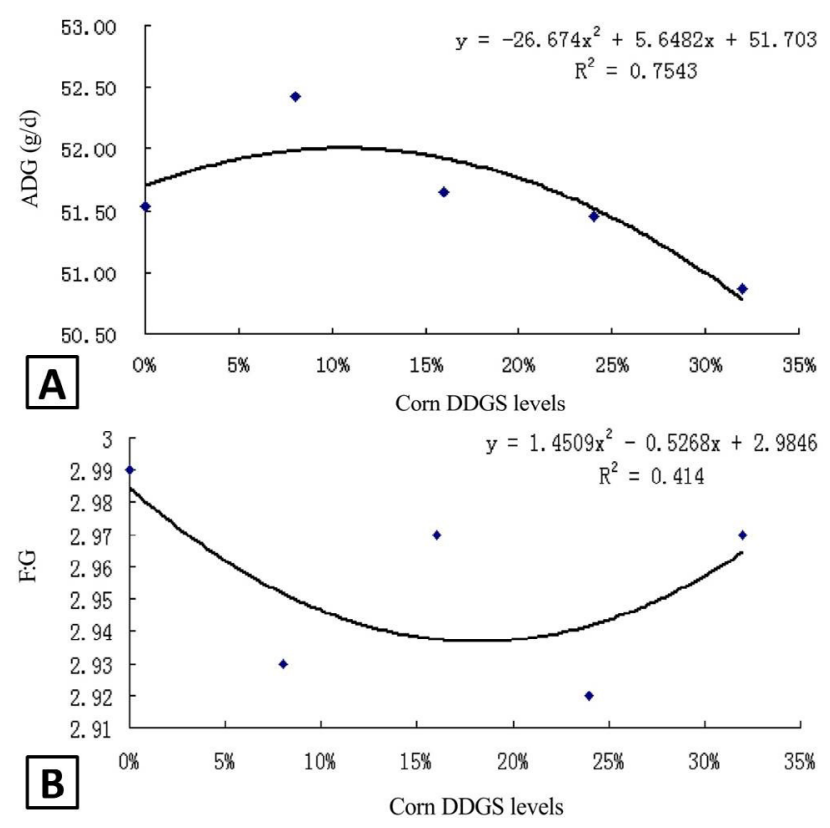

Fig. 1. Quadratic regression analysis: A, the regression relationship between DDGS and ADG; B, the regression relationship between DDGS and F:G.

\section{Economic benefit analysis}

In almost all poultry production systems, the feed costs accounted for $70-75 \%$ of producer expenses (Amerah et al., 2007; Adamski et al., 2011). For poultry production, reducing production costs is the key to profitability. On one hand, the nutritional value of corn DDGS is high that can be widely used in poultry (Abudabos et al., 2017; Shim et al., 2018; Wang et al., 2018; Ruan et al., 2018). On the other hand, corn DDGS is much cheaper than corn and soybean meals. Thus an increase in DDGS inclusion in the diet can significantly reduce the feed cost. In the present study, the economic benefit of corn DDGS added to meat ducks was assessed. The results presented in Table III showed that cost per tonne of feed was decreased with the increase of DDGS addition level, which is in accordance with the study of Adamski et al. (2011) and Kowalczyk et al. (2012). With the increase of DDGS addition level, the unit weight gain cost was gradually decreased, namely, 
$0 \%$ DDGS $>8 \%$ DDGS $>16 \%$ DDGS $>24 \%$ DDGS $>$ $32 \%$ DDGS. Owing to cheaper costs of DDGS compared to soybean meal, the results justify the addition of corn DDGS in diet which can significantly improve economic benefits. Moreover, addition of corn DDGS in meat duck diets did not influence the growth performance of ducks, therefore, the unit weight gain cost is correspondingly lower.

Table III.- Effects of corn DDGS on economic benefit of meat ducks.

\begin{tabular}{lccccc}
\hline Item & Costs $^{2}$ & F:G & UWGC $^{3}$ & $\begin{array}{c}\text { Relative } \\
\text { cost }^{4}\end{array}$ & $\begin{array}{c}\text { Relative } \\
\text { economic } \\
\text { benefit }\end{array}$ \\
\hline $\mathrm{T} 0^{1}$ & 2323 & 2.99 & 6.95 & - & - \\
$\mathrm{T} 1$ & 2282 & 2.93 & 6.69 & $0.26^{*}$ & $3.79^{\#}$ \\
$\mathrm{~T} 2$ & 2246 & 2.97 & 6.67 & $0.28^{*}$ & $4.02^{\#}$ \\
$\mathrm{~T} 3$ & 2216 & 2.92 & 6.47 & $0.48^{*}$ & $6.90^{\#}$ \\
$\mathrm{~T} 4$ & 2175 & 2.97 & 6.46 & $0.49^{*}$ & $7.05^{\#}$ \\
\hline
\end{tabular}

${ }^{1} \mathrm{~T} 0$, control group: 0\% DDGS; T1, 8\% DDGS; T2, 16\% DDGS; T3, 24\% DDGS; T4, 32\% DDGS. ${ }^{2}$ The cost of feed was calculated according to market price. ${ }^{3}$ means unit weight gain cost. $\mathrm{UWGC}=\mathrm{F}: \mathrm{G} \times$ feed unit price. ${ }^{4}$ relative costs and relative economic benefits are compared with control group (T0). *, decrease; \#, increase.

\section{CONCLUSION}

Taken together, our results demonstrate that the increase of DDGS in feed did not negatively affect the growth performance and subsequently can decrease the unit weight gain cost. In order to maintain a lower F:G conditions to minimize the cost of feed, the optimized DDGS added level is proposed to be $18.15 \%$. However, a high level of corn DDGS in meat duck diets is also feasible and may warrant future investigations.

\section{ACKNOWLEDGMENTS}

This research was supported by grants from the National Top Discipline Construction Project of Guizhou Province: Geography in Guizhou Normal University (85 2017 Qianjiao Keyan Fa); the Doctoral Launched Scientific Research Program of Guizhou normal university (GZNUD(2018)26); and the Project of Innovation Program for Postgraduate Education of Guizhou Province (04 2016 Qianjiao Yanhe GZS Zi).

\section{Statement of Conflict of interest}

The authors have declared no conflict of interest.

\section{REFERENCES}

Abudabos, A.M., Al-Atiyat, R.M., Stanley, D., Aljassim, R. and Albatshan, H.A., 2017. The effect of corn distiller's dried grains with solubles (DDGS) fortified with enzyme on growth performance of broiler. Environ. Sci. Pollut. Res. Int., 24: 2141221421. https://doi.org/10.1007/s11356-017-9808-5

Adamski, M.P., Kowalczyk, A.M., Łukaszewicz, E.T. and Korzeniowska, M., 2011. Effects of sex and inclusion of dried distillers grains with solubles on slaughter yield and meat characteristics of Pekin ducks. Br. Poult. Sci., 52: 742-749. https://doi.org /10.1080/00071668.2011.639745

Alagón, G., Arce, O., Serrano, P., Ródenas, L., MartínezParedes, E., Cervera, C., Pascual, J.J. and Pascual, M., 2015. Effect of feeding diets containing barley, wheat and corn distillers dried grains with solubles on carcass traits and meat quality in growing rabbits. Meat Sci., 101: 56-62. https://doi.org/10.1016/j. meatsci.2014.10.029

Amerah, A.M., Ravindran, V., Lentle, R.G. and Thomas, D.G., 2007. Feed particle size: Implications on the digestion and performance of poultry. World's Poult. Sci. J., 63: 439-453. https://doi.org/10.1017/ S0043933907001560

Diógenes, A.F., Castro, C., Miranda, A.C., OlivaTeles, A. and Peres, H., 2018. Dietary replacement of fishmeal by corn distillers dried grains with solubles (DDGS) in diets for turbot (Scophthalmus maximus, Linneaus 1758) juveniles. Aquaculture, 492: 113-122. https://doi.org/10.1016/j. aquaculture.2018.04.005

Dozier, W.A., McCafferty, K. and Hess, J.B., 2016. Growth and meat yield responses of Ross $\times$ Ross 708 male broilers fed diets formulated with distillers dried grains with solubles varying in ether extract content and inclusion rate from 1 to 49 days of age. J. appl. Poult. Res., 26: 23-27. https://doi. org/10.3382/japr/pfw043

Fastinger, N.D., Latshaw, J.D. and Mahan, D.C., 2006. Amino acid availability and true metabolizable energy content of corn distillers dried grains with solubles in adult cecectomized roosters. Poult. Sci., 85: 1212-1216. https://doi.org/10.1093/ ps/85.7.1212

Hanson, A.R., Wang, L. and Johnston, L.J., 2015. Effect of feeding peroxidized dried distillers grains with solubles to sows progeny on growth performance and metabolic oxidative status of nursery pigs. $J$. Anim. Sci., 93: 135-146. https://doi.org/10.2527/ 
jas.2014-7371

He, M.L., Xu, L., Yang, W.Z., Gibb, D. and Mcallister, T.A., 2014. Effect of low-oil corn dried distillers' grains with solubles on growth performance, carcass traits and beef fatty acid profile of feedlot cattle. Can. J. Anim. Sci., 94: 343-347. https://doi. org/10.4141/cjas2013-196

Huang, Z., Urriola, P.E. and Shurson, G.C., 2018. Prediction of digestible and metabolizable energy of corn distillers dried grains with solubles for growing pigs using in vitro digestible nutrients. $J$. Anim. Sci., 96: 1818-1824. https://doi.org/10.1093/ jas/sky102

Kim, J.S., Hosseindoust, A.R., Shim, Y.H., Lee, S.H., Choi, Y.H., Kim, M.J., Oh, S.M., Ham, H.B., Kumar, A. and Chae, B.J., 2018. Processing diets containing corn distillers'dried grains with solubles in growing broiler chickens: effects on performance, pellet quality, ileal amino acids digestibility, and intestinal microbiota. Poult. Sci., 97: 2411-2418. https://doi.org/10.3382/ps/pey075

Kowalczyk, A., Lukaszewicz, E., Adamski, M. and Kuzniacka, J., 2012. Carcass composition and meat characteristics of Pekin ducks in relation to age at slaughter and level of maize distiller's dried grains with solubles in diets. J. Anim. Feed Sci., 40: 157167. https://doi.org/10.22358/jafs/66060/2012

Liu, K.S. and Han, J.C., 2011. Changes in mineral concentrations and phosphorus profile during dry-grind process of corn into ethanol. Bioresour. Technol., 102: 3110-3118. https://doi.org/10.1016/j. biortech.2010.10.070

Min, Y.N., Li, L.L., Liu, S.K., Zhang, J., Gao, Y.P. and Liu, F.Z., 2015. Effects of dietary distillers dried grains with soluble (DDGS) on growth performance, oxidative stress, and immune function in broiler chickens. J. appl. Poult. Res., 24: 23-29. https://doi.org/10.3382/japr/pfv002

Oczkowicz, M., Szmatoła, T., Świątkiewicz, M., Pawlina-Tyszko, K., Gurgul, A. and Ząbek, T., 2018. Corn dried distillers grains with solubles (CDDGS) in the diet of pigs change the expression of adipose genes that are potential therapeutic targets in metabolic and cardiovascular diseases. BMC Genom., 19: 864. https://doi.org/10.1186/ s12864-018-5265-X

Ruan, D., Fouad, A.M., Fan, Q.L., Chen, W., Xia, W.G., Wang, S. and Zheng, C.T., 2018. Effects of corn dried distillers' grains with solubles on performance, egg quality, yolk fatty acid composition and oxidative status in laying ducks. Poult. Sci., 97: 568-577. https://doi.org/10.3382/ps/pex331

Ruan, D., Jiang, S.Q., Hu, Y.J., Ding, F.Y., Fan, Q.L., Chen, F. and Wang, Y., 2017. Effects of corn distillers dried grains with solubles on performance, oxidative status, intestinal immunity and meat quality of Chinese yellow broilers. J. Anim. Physiol. Anim. Nutr., 101: 1185-1193. https://doi. org/10.1111/jpn.12637

Shim, M.Y., Pesti, G.M., Bakalli, R.I., Tillman, P.B. and Payne, R.L., 2011. Evaluation of corn distillers dried grains with solubles as an alternative ingredient for broilers. Poult. Sci., 90: 369-376. https://doi.org/10.3382/ps.2010-00727

Shim, Y.H., Kim, J.S., Hosseindoust, A., Choi, Y.H. and Chae, B.J., 2018. Investigating meat quality of broiler chickens fed on heat processed diets containing corn distillers dried grains with solubles. Korean J. Fd. Sci. Anim. Resour., 38: 629-635.

Testroet, E.D., Beitz, D.C., Neil, M.R., Mueller, A.L., Ramirez-Ramirez, H.A. and Clark, S., 2018. Feeding reduced-fat dried distillers grains with solubles to lactating Holstein dairy cows does not alter milk composition or cause late blowing in cheese. J. Dairy Sci., 101: 1-13. https://doi. org/10.3168/jds.2017-13699

Villela, C.C.E.J., Cox, R.B., Shurson, G.C., Compart, K.M., Urriola, P.E. and Johnston, L.J., 2017. Effects of adding minimally refined cottonseed oil or crude glycerol to diets containing $40 \%$ corn distiller's dried grains with solubles on growth performance, carcass characteristics, and pork fat firmness of growing-finishing pigs. J. Anim. Sci., 95: 30573067. https://doi.org/10.2527/jas.2017.1383

Wang, H.Y., Bai, S.P., Ding, X.M., Wang, J.P., Zeng, Q.F., Su, Z.W., Xuan, Y. and Zhang, K.Y., 2018. Nitrogen-corrected apparent metabolizable energy value of corn distillers dried grains with solubles for laying hens. Anim. Feed Sci. Tech., 238: 66-72. https://doi.org/10.1016/j.anifeedsci.2018.02.002

Wang, Z., Cerrate, S., Coto, C., Yan, F. and Waldroup, P.W., 2007. Utilization of distillers dried grains with soluble (DDGS) in broiler diets using a standardized nutrient matrix. Int. J. Poult. Sci., 6: 470-477. https://doi.org/10.3923/ijps.2007.470.477

Xie, H.D., Bu, L.J., Zhong, Z.Z., Huang, Y., Peng, X.W. and Li, D.J., 2016. Effects of sorghum distillers dried grains with solubles on the carcass characteristics and muscle quality of China micro duck drakes aged from 4 to 8 weeks. Poult. Sci., 95: 2633-2639. https://doi.org/10.3382/ps/pew166 Xu, G., Baidoo, S.K., Johnston, L.J., Bibus, D., Cannon, 
J.E. and Shurson, G.C., 2010. Effects of feeding diets containing increasing content of corn distillers dried grains with solubles to grower-finisher pigs on growth performance, carcass composition, and pork fat quality. J. Anim. Sci., 88: 1398-1410. https://doi.org/10.2527/jas.2008-1404
Yang, X., Nath, C., Doering, A., Goihl, J. and Baidoo, S.K., 2017. Effects of liquid feeding of corn condensed distiller's solubles and whole stillage on growth performance, carcass characteristics, and sensory traits of pigs. J. Anim. Sci. Biotechnol., 8: 9. https://doi.org/10.1186/s40104-016-0140-6 